\title{
Metode Cooperative Learning dalam Pembelajaran Pendidikan Agama Islam
}

\author{
SYAHRAINI TAMBAK \\ Fakultas Agama Islam (FAI) Universitas Islam Riau (UIR) Pekanbaru \\ Jl. Kaharuddin Nasution, No. 113, Perhentian Marpoyan Pekanbaru 28284 \\ e-mail: syahraini tambak@yahoo.co.id
}

\begin{abstract}
Abstrak: Manusia sebagai makhluk sosial senantiasa memiliki ketergantungan dengan orang lain. Manusia membutuhkan interaksi-komunikasi-sosialisasi dengan manusia lainnya yang kemudian terbentuklah komunitas bermasyarakat. Dalam berbagai kegiatan, manusia sewajarnya melakukan kegiatan saling membantu antar sesama termasuk dalam kegiatan memperoleh pengetahuan. Dengan kata lain, melalui metode kooperatif maka upaya dengan bekerja sama dapat menyelesaikan persoalan guna meningkatkan kemampuan peserta didik dalam memahami materi pelajaran. Metode cooperative learning dapat memotivasi peserta didik untuk berfikir kritis sekaligus dialogis, kreatif dan interaktif yakni problem solving atau pengajuan masalah-masalah yang dituangkan dalam bentuk pertanyaan. Permasalahan dalam bentuk pertanyaanpertanyaan tersebut kemudian diupayakan untuk dicari jawabannya baik secara individu maupun bersama dengan pihak lain, misalnya sesama peserta didik maupun dengan pengajar sendiri. Metode cooperative learning dalam pembelajaran pendidikan agama Islam adalah cara menyajikan pembelajaran dengan belajar bersama berbentuk kelompok kecil yang terstruktur di dalamnya peserta didik melakukan aktivitas belajar saling membantu guna meningkatkan kemampuan kognitif, afektif, dan psikomotorik dalam memahami materi pelajaran dan memecahkan masalah secara kolektif sesuai dengan indikator pembelajaran PAI yang telah ditetapkan.
\end{abstract}

Kata kunci: Metode, Cooperative Learning, PAI.

\section{PENDAHULUAN}

Pembelajaran koperatif sesuai dengan fitrah manusia sebagai makhluk sosial yang penuh ketergantungan dengan orang lain, mempunyai tujuan dan tanggung jawab bersama, pembegian tugas, dan rasa senasib. Dengan memanfaatkan kenyatan itu, belajar berkelompok secara koperatif, peserta didik dilatih dan dibiasakan untuk saling berbagi (sharing) pengetahuan, pengalaman, tugas, tanggung jawab. Saling membantu dan berlatih berinteraksi-komunikasisosialisasi karena koperatif adalah miniature dari hidup bermasyarakat, dan belajar menyadari kekurangan dan kelebihan masing-masing.

Jadi metode pembelajaran kooperatif adalah kegiatan pembelajaran dengan cara berkelompok untuk bekerja sama saling membantu mengkontruksu konsep, menyelesaikan persoalan, atau inkuiri. Menurut teori dan pengalaman agar kelompok kohesif (kompakpartisipatif), tiap anggota kelompok terdiri dari 4-5 orang, peserta didik heterogen (kemampuan, gender, karekter), ada kontrol dan fasilitasi, dan meminta tanggung jawab hasil 
kelompok berupa laporan atau presentasi.

\section{PENGERTIAN METODE COOPERATIVE LEARNING}

Dalam proses belajar mengajar dikenal metode cooperative learning atau pembelajaran gotong royong. Cooperative learning terdiri dari dua kata yaitu Cooperative dan Learning. Cooperative berarti "acting together with a common purpose" (Wehmeier, 2000: 276). Usman (2002: 14) mendefinisikan cooperative sebagai belajar kelompok atau bekerjasama. Menurut Burton yang dikutip oleh Nasution, kooperatif atau kerjasama ialah cara individu mengadakan relasi dan bekerjasama dengan individu lain untuk mencapai tujuan bersama (Nasution, 2000: 148).

Sedangkan learning adalah "the process through which experience causes permanent change in knowledge and behavior" yakni proses melalui pengalaman yang menyebabkan perubahan permanent dalam pengetahuan dan perilaku (Woofolk, 1996: 196). Senada dengan hal itu Arthur T. Jersild, yang dikutip Syaiful Sagala, mendefinisikan bahwa learning adalah "modification of behavior through experience and training" yakni pembentukan perilaku melalui pengalaman dan latihan (Sagala: 2003: 12). Dia menambahkan bahwa learning sebagai kegiatan memperoleh pengetahuan, perilaku dan ketrampilan dengan cara mengolah bahan ajar (Sagala: 2003: 13).

David dan Roger Johnson mendefinisikan $C L$ adalah "a teaching strategy in which small teams, each with students of different levels of ability, use a variety of learning activities to improve their understanding of a subject." (Strategi pembelajaran dalam bentuk kelompok-kelompok kecil dimana setiap peserta didik memiliki tingkat kemampuan berbeda, dengan menggunakan berbagai macam aktifitas belajar untuk meningkatkan pemahaman terhadap materi). Asep Gojwan mendefinisikan cooperative learning sebagai suatu model pembelajaran yang menekankan aktivitas kolaboratif peserta didik dalam belajar yang berbentuk kelompok kecil untuk mencapai tujuan yang sama dengan menggunakan berbagai macam aktifitas belajar guna meningkatkan kemampuan peserta didik dalam memahami materi pelajaran dan memecahkan masalah secara kolektif.

Setiap anggota kelompok bukan hanya belajar materi apa yang diajarkan tetapi juga membantu anggota yang lain untuk belajar. Model pembelajaran ini menganut prinsip saling ketergantungan positif (positive interdependence), tanggung jawab perseorangan (individual accountability), tatap muka (face to face interaction), keterampilan sosial (social skill) dan proses kelompok (group processing) (David \& Johnson, 1999: 58).

Inti dari cooperative learning ini adalah konsep synergy, yakni energi atau tenaga yang terhimpun melalui kerjasama sebagai salah satu fenomena kehidupan masyarakat (Sagala, 2002: 177). Penerapannya beranjak dari konsep Dewey yang dikutip oleh Yurnetti bahwa "classroom should mirror the large society and be a laboratory for real life learning" (Yurnetti, 2002: 1). Terjemahan bebasnya bahwa kelas seharusnya mencerminkan keadaan masyarakat luas dan menjadi laboratorium untuk belajar kehidupan nyata. Jadi cooperative learning dirancang untuk memanfaatkan fenomena kerjasama/gotong royong dalam pembelajaran yang menekankan 
terbentuknya hubungan antara peserta didik yang satu dengan yang lainnya, terbentuknya sikap dan perilaku yang demokratis serta tumbuhnya produktivitas kegiatan belajar peserta didik.

Metode cooperative learning adalah metode pembelajaran yang berfokus pada penggunaan kelompok kecil peserta didik untuk bekerja sama dalam memaksimalkan kondisi belajar untuk mencapai tujuan belajar (Nurhadi, 2004: 112). Metode ini dengan demikian sebuah pembelajaran yang menekankan pada sikap atau perilaku bersama dalam bekerja atau membantu di antara sesama, struktur bekerja sama yang teratur dalam kelompok yang terdiri atas dua orang atau lebih. Paradigma lama tentang proses pembelajaran yang bersumber pada teori tabula rasa John Lock dimana pikiran seorang anak seperti kertas kosong dan siap menunggu coretancoretan dari gurunya sepertinya kurang tepat lagi digunakan oleh para pendidik saat ini. Tuntutan pendidikan sudah banyak berubah. Guru PAI perlu menyusun dan melaksanakan kegiatan belajar mengajar dimana anak dapat aktif membangun pengetahuannya sendiri. Hal ini sesuai dengan pandangan kontruktivisme yaitu keberhasilan belajar tidak hanya bergantung pada lingkungan atau kondisi belajar, tetapi juga pada pengetahuan awal peserta didik. Belajar melibatkan pembentukan "makna" oleh peserta didik dari apa yang mereka lakukan, lihat,dan dengar.

Penerapan metode cooperative learning dalam pembelajaran dimaksudkan untuk memperkuat pelajaran akademik setiap anggota kelompok dengan tujuan agar para peserta didik lebih berhasil dalam belajar dari pada belajar sendiri. Sebagai konsekuensinya untuk menjamin bahwa setiap peserta didik berhasil dan benar-benar bertanggung jawab terhadap pelajarannya sendiri maka setiap peserta didik harus diberi tanggung jawab secara individual untuk mengerjakan bagian tugasnya sendiri dan mengetahui apa yang telah ditargetkan dan yang harus dipelajari. Oleh karena itu, unsur terpenting yang harus dipahami oleh para guru adalah apabila tugas dibagi dalam kelompok jangan sampai hanya diperiksa/dievaluasi atau tidaknya tugas itu dikerjakan secara kelompok, melainkan harus terjadi interdepensi tugas antara kelompok karena tujuan cooperative learning bukan terselesaikannya tugas-tugas kelompok, tetapi para peserta didik belajar dalam kehidupan kelompok yang mampu saling membelajarkan antar anggota kelompoknya.

$\begin{array}{llr}\text { Ketergantungan yang positif } \\ \text { dalam cooperative learning } & \text { akan } \\ \text { memotivasi para peserta didik untuk } \\ \text { bertanggung jawab terhadap }\end{array}$
keberhasilan temannya, kemampuan untuk saling mempengaruhi dalam membuat alasan dan kesimpulan antara satu dengan yang lain, social modeling, dukungan social, apabila guru dalam menstruktur kelompok dalam bentuk interaksi tatap muka. Interaksi tatap muka selain memberikan motivasi yang penting bagi performans seorang peserta didik juga akan meningkatkan saling mengetahui keberhasilan akademik setiap peserta didik dan personal masing-masing. Cara ini akan mendukung dan memperkuat makna ketergantungan yang positif dan mempermudah peserta didik untuk mempromosikan keberhasilan siwa yang lain sebagai keberhasilan kelompok.

Penguasaan keterampilan sosial dalam cooperative learning perlu dimiliki para peserta didik terutama dalam menyelesaikan tugas-tugas kelompok. Namun karena para peserta 
didik baru saja ditempatkan dalam kelompok-kelompok dan diharapkan dapat menerapkan keterampilan sosial yang tepat, maka tidak secara otomatis mereka akan mampu menerapkannya dengan baik. Sedangkan dalam Cooperative learning para peserta didik dituntut untuk memiliki kemampuan interaksi seperti mengajukan pendapat, mendengarkan opini teman, menampilkan kepemimpinan, kompromi, negoisasi dan klasifikasi secara teratur untuk menyelesaikan tugas-tugasnya. Oleh karena itu, untuk memenuhi persyaratan tersebut, guru perlu menerangkan dan mempraktekkan tingkah laku dan sikap-sikap interaksi sosial yang diharapkan untuk dilakukan.

Proses kelompok terjadi ketika anggota kelompok mendiskusikan seberapa baik mereka mencapai tujuan dan memelihara kerjasama yang efektif. Para peserta didik perlu mengetahui tingkat-tingkat keberhasilan pencapaian tujuan dan efektivitas kerjasama yang telah dilakukan. Untuk memperoleh informasi itu, para peserta didik perlu mengadakan perbaikanperbaikan secara sistematis tentang bagaimana mereka telah bekerja sama sebagai satu tim, dalam hal; Seberapa baik tingkat pencapaian tujuan kelompok; Bagaimana mereka saling membantu satu sama lain; Bagaimana mereka bersikap dan bertingkah laku positif untuk memungkinkan setiap individu dan kelompok secara keseluruhan menjadi berhasil; dan apa yang mereka butuhkan untuk melakukan tugas-tugas yang akan datang supaya lebih berhasil.

\section{Sesuai dengan filosofi}

kontruktivisme, bahwa dalam proses pembelajaran guru tidak mendokrinasi gagasan saintifik, sehingga sistem perubahan gagasan peserta didik adalah peserta didik itu sendiri. Guru hanya berperan sebagai fasilitator, penyedia "kondisi" supaya proses pembelajaran dalam upaya memperoleh konsep pengukuran volume berlangsung benar. Beberapa pola yang harus dikembangkan oleh guru yang mengacu kepada cooperative learning sesuai dengan filosofi kontruktivisme adalah; guru PAI mengarahkan peserta didik untuk melaksanakan diskusi kelompok; mendorong peserta didik untuk mengadakan penelitian sederhana lewat alat peraga yang dimanipulasi; dan guru PAI mendorong peserta didik untuk melaksanakan kegiatan praktis dan memberi peluang untuk mempertanyakan dan memodifikasi serta mempertajam gagasannya.

Metode cooperative learning yang dapat memotivasi peserta didik untuk berfikir kritis sekaligus dialogis, kreatif dan interaktif yakni problem posing atau pengajuan masalah-masalah yang dituangkan dalam bentuk pertanyaan. Permasalahan dalam bentuk pertanyaanpertanyaan tersebut kemudian diupayakan untuk dicari jawabannya baik secara individu maupun bersama dengan pihak lain, misalnya sesama peserta didik maupun dengan pengajar sendiri.

Metode cooperative learning diharapkan dapat memacu peserta didik untuk menemukan pengetahuan yang bukan diakibatkan dari ketidaksengajaan melainkan melalui upaya untuk mencari hubungan-hubungan dalam informasi yang dipelajarinya. Semakin luas informasi yang dimiliki akan semakin mudah pula menemukan hubunganhubungan tersebut. Pada akhirnya, penemuan pertanyaan serta jawaban yang dihasilkan terhadapnya dapat menyebabkan perubahan dan ketergantungan pada penguatan luar pada rasa puas akibat keberhasilan menemukan sendiri, baik berupa pertanyaan atau masalah maupun jawaban atas permasalahan yang 
diajukan. Belajar menemukan dan memecahkan masalah berkonsekuensi pada adanya eksplorasi terhadap sejumlah alternatif yang akhirnya menciptakan dorongan berfikir hingga diperolehnya pengetahuan.

Cooperative learning menekankan pada sikap atau perilaku bersama dalam bekerja atau membantu di antara sesama dalam struktur kerjasama yang teratur dalam kelompok, yang terdiri dari dua orang atau lebih. Pembelajaran kooperatif adalah salah satu bentuk pembelajaran yang berdasarkan faham konstruktivis. Pembelajaran kooperatif merupakan strategi belajar dengan sejumlah peserta didik sebagai anggota kelompok kecil yang tingkat kemampuannya berbeda. Dalam menyelesaikan tugas kelompoknya, setiap peserta didik anggota kelompok harus saling bekerja sama dan saling membantu untuk memahami materi pelajaran. Dalam pembelajaran kooperatif, belajar dikatakan belum selesai jika salah satu teman dalam kelompok belum menguasai bahan pelajaran.

Dapat ditegaskan di sini bahwa yang dimaksud dengan metode cooperative learning dalam pembelajaran pendidikan agama Islam adalah cara menyajikan pembelajaran dengan belajar bersama berbentuk kelompok kecil yang terstruktur di dalamnya peserta didik melakukan aktivitas belajar saling membantu guna meningkatkan kemampuan kognitif, apektif, dan psikomotorik dalam memahami materi pelajaran dan memecahkan masalah secara kolektif untuk mencapai tujuan yang sama sesuai dengan indikator pembelajaran yang telah ditetapkan.

Berdasarkan definisi yang dikemukakan di atas tentang metode cooperative learning dalam pembelajaran PAI terdapat beberapa variabel yang menuntut untuk dijelaskan. Hal ini diperlukan untuk lebih memberikan pemahaman pada calon guru PAI dan juga para guru PAI yang tersebar di seluruh Indonesia mengenai aspek-aspek penting dalam metode cooperative learning tersebut. Untuk itu hal-hal penting yang perlu untuk dijelaskan adalah;

Pertama, cara menyajikan pembelajaran. Cara menyajikan ini merupakan langkah-langkah penting yang dipergunakan guru PAI untuk mensukseskan dirinya dalam proses pembelajaran pendidikan agama Islam. Hal yang disajikan oleh guru PAI adalah tentu materi pendidikan agama Islam. Bila dikaitkan dengan cara penyajian hal ini manggambarkan bahwa metode cooperative leraning tersebut dipergunakan oleh guru PAI dalam mengajarkan materi pembelajaran. Peserta didik mudah memahami materi pembelajaran PAI tersebut secara maksimal baik, intelektual, emosional, maupun keterampilan melalui metode cooperative learning. Materi pembelajaran berjalan di atas langkahlangkah metode cooperative learning tersebut, dan di sinilah letak cara penyajian tersebut.

Kedua, belajar bersama. Hal ini menggambarkan bahwa peserta didik dalam belajar dengan mengerjakan sesuatu bersama-sama dengan saling membantu satu sama lain sebagai satu tim. Cooperatif menyangkut mengerjakan sesuatu bersama-sama dengan saling membantu satu sama lain sebagai satu tim. Cooperative learning menggambarkan belajar bersama-sama, saling membantu antara satu sama lain dalam belajar dan memastikan bahwa setiap orang dalam kelompok mencapai tujuan atau tugas yang telah ditentukan sebelumnya.

Ketiga, berbentuk kelompok kecil yang terstruktur. Berbentuk kelompok kecil di mana peserta didik 
belajar bersama dalam kelompok yang tidak besar biasanya terdiri dari tiga atau empat orang dan memastikan bahwa setiap orang dalam kelompok mencapai tujuan atau tugas yang telah ditentukan sebelumnya. Metode cooperative learning merupakan salah satu model pembelajaran yang mendukung pembelajaran kontekstual. Sistem pengajaran cooperative learning sebagai sistem kerja/ belajar kelompok yang terstruktur. Pembelajaran bersama berkolompok yang dinamakan terstruktur tersebut termasuk di dalamnya lima unsur pokok yaitu saling ketergantungan positif, tanggung jawab individual, interaksi personal, keahlian bekerja sama, dan proses kelompok. Falsafah yang mendasari pembelajaran cooperative learning adalah "homo homini socius" yang menekankan bahwa manusia adalah makhluk sosial.

\section{Saling ketergantungan}

menggambarkan bahwa keberhasilan suatu karya sangat bergantung pada usaha setiap anggotanya. Untuk menciptakan kelompok kerja yang efektif, pengajar perlu menyusun tugas sedemikian rupa sehingga setiap anggota kelompok harus menyelesaikan tugasnya sendiri agar yang lain dapat mencapai tujuan mereka. Tanggung jawab perseorangan menggambarkan bahwa jika tugas dan pola penilaian dibuat menurut prosedur model pembelajaran cooperative learning, setiap peserta didik akan merasa bertanggung jawab untuk melakukan yang terbaik. Guru PAI yang efektif dalam menggunakan metode pembelajaran cooperative learning membuat persiapan dan menyusun tugas sedemikian rupa sehingga masing-masing anggota kelompok harus melaksanakan tanggung jawabnya sendiri agar tugas selanjutnya dalam kelompok bisa dilaksanakan.

Tatap muka menggambarkan bahwa dalam pembelajaran cooperative learning setiap kelompok harus diberikan kesempatan untuk bertatap muka dan berdiskusi. Kegiatan interaksi ini akan memberikan para pembelajar untuk membentuk sinergi yang menguntungkan semua anggota. Inti dari sinergi ini adalah menghargai perbedaan, memanfaatkan kelebihan, dan mengisi kekurangan. Komunikasi antar anggota menggambarkan bahwa unsur ini menghendaki agar para pembelajar dibekali dengan berbagai keterampilan berkomunikasi, karena keberhasilan suatu kelompok juga bergantung pada kesediaan para anggotanya untuk saling mendengarkan dan kemampuan mereka untuk mengutarakan pendapat mereka. Keterampilan berkomunikasi dalam kelompok juga merupakan proses panjang. Namun, proses ini merupakan proses yang sangat bermanfaat dan perlu ditempuh untuk memperkaya pengalaman belajar dan pembinaan perkembangan mental dan emosional para peserta didik. Evaluasi proses kelompok menggambarkan bahwa guru PAI perlu menjadwalkan waktu khusus bagi kelompok untuk mengevaluasi proses kerja kelompok dan hasil kerja sama mereka agar selanjutnya bisa bekerja sama dengan lebih efektif.

$$
\text { Keempat, peserta didik }
$$
melakukan aktivitas belajar saling membantu guna meningkatkan kemampuan kognitif, apektif, dan psikomotorik. Apa yang telah diuraikan di atas bahwa metode cooperative learning mengandung sebuah proses pembelajaran di mana terjadi saling ketergantungan. Di mana menggambarkan bahwa keberhasilan suatu karya sangat bergantung pada usaha setiap anggotanya. Untuk menciptakan kelompok kerja yang efektif, pengajar perlu menyusun tugas sedemikian rupa sehingga setiap anggota kelompok harus menyelesaikan 
tugasnya sendiri agar yang lain dapat mencapai tujuan mereka.

Hal ini menggambarkan bahwa pembelajaran dengan metode ini menuntut guru untuk mengarahkan peserta didik agar saling membantu satu sama lain untuk meningkatkan kecerdasan kognitif, apektif dan psikomotorik. Tiga ranah ini menjadi hal yang harus dicapai oleh peserta didik dalam proses pembelajaran PAI pada kelompoknya. Peserta didik diharapkan saling mambantu dan mengarahkan agar pembelajaran di kelompoknya dapat tercapai dengan maksimal. Aktivitas belajar yang berlangsung tak sekedar belajar biasa, akan tetapi terjadi sebuah proses pembelajaran dalam kelompok dengan terstruktur dan terarah.

\section{Kelima dalam memahami materi} pelajaran dan memecahkan masalah secara kolektif. Ciri metode cooperative learning Salvin yaitu akuntabilitas individual, interaksi tatap muka, keterampilan seusia, proses kelompok dan saling ketergantungan yang positif. Ketergantungan positif adalah perasaan diantara anggota kelompok dimana keberhasilan seseorang merupakan keberhasilan yang lainnya pula atau sebaliknya. Untuk menciptakan suasana tersebut, guru perlu merancang struktur kelompok, tugas-tugas kelompok yang memungkinkan setiap peserta didik untuk belajar mengevaluasi dirinya dengan teman kelompoknya dalam penguasaan dan kemampuan memahami bahan pelajaran (Salvin, 1995: 156). Kondisi seperti ini memungkinkan setiap peserta didik merasa adanya ketergantungan secara positif pada anggota kelompok lainnya dalam mempelajari dan menyelesaikan tugas-tugas yang menjadi tanggung jawabnya, yang mendorong setiap anggota kelompok untuk bekerja sama.
Keenam, untuk mencapai tujuan yang sama sesuai dengan indikator pembelajaran yang telah ditetapkan. Akhir dari proses pembelajaran dengan metode cooperative learning ini adalah di mana semua peserta didik dapat mencapai tujuan pembelajaran sesuai dengan indikator pembelajaran yang telah ditetapkan. Hal inilah juga yang menjadi semacam pengikat dan arah penting dalam proses pembelajaran dengan metode ini di mana peserta didik harus sampai pada tujuan utama yang telah ditetapkan sebelumnya. Aktivitas belajar peserta didik dalam kelompok di bawah bimbingan guru harus mencapai tujuan tersebut dan peserta didik dapat memahami secara maksimal baik aspek kognitif, apektif dan psikomotorik.

\section{KELEBIHAN DAN KELEMAHAN Kelebihan}

Metode pembelajaran cooperative learning adalah salah satu metode pembelajaran yang menempatkan peserta didik sebagai subjek pembelajaran (student oriented). Dengan suasana kelas yang demokratis, yang saling membelajarkan memberi kesempatan peluang lebih besar dalam memberdayakan potensi peserta didik secara maksimal. Metode pembelajaran cooperative learning akan dapat memberikan nunasa baru di dalam pelaksanaan pembelajaran dalam mata pelajaran PAI yang diampu guru. Karena pembelajaran cooperative learning dan beberapa hasil penelitian baik pakar pendidikan dalam maupun luar negeri telah memberikan dampak luas terhadap keberhasilan dalam proses pembelajaran. Dampak tersebut tidak saja kepada guru akan tetapi juga pada peserta didik, dan interaksi edukatif muncul dan terlihat peran dan fungsi dari guru maupun peserta didik. 
Peran guru dalam pembelajaran cooperative learning sebagai fasilitator, moderator, organisator dan mediator terlihat jelas. Kondisi ini peran dan fungsi peserta didik terlihat, keterlibatan semua peserta didik akan dapat memberikan suasana aktif dan pembelajaran terkesan demokratis, dan masing-masing peserta didik punya peran dan akan memberikan pengalaman belajarnya kepada peserta didik lain. Berikut ini akan dikemukakan beberapa keuntungan yang diperoleh baik oleh guru maupun peserta didik di dalam pelaksanaan pembelajaran menggunakan metode cooperative learning.

Pertama, melalui cooperative learning menimbulkan suasana yang baru dalam pembelajaran. Hal ini dikarenakan sebelumnya hanya dilaksanakan model pembelajaran secara konvensional yaitu camah dan tanya jawab. Metode tersebut ternyata kurang memberi motivasi dan semangat kepada peserta didik untuk belajar. Dengan digunakannva model cooperative learning, maka tampak suasana kelas menjadi lebih hidup dan lebih bermakna.

Kedua, membantu guru PAI dalam mengidentifikasikan kesulitan-kesulitan yang dihadapi dan mencarikan alternatif pemecahannya. Dari hasil penelitian tindakan pelaksanaan cooperative learning dengan diskusi kelompok ternyata mampu membuat peserta didik terlibat aktif dalam kegiatan belajar.

Ketiga, penggunaan cooperative learning merupakan suatu metode yang efektif untuk mengembangkan program pembelajaran terpadu. Dengan cooperative learning peserta didik tidak hanya dapat mengembangkan kemampuan aspek kognitif saja melainkan mampu mengembangkan aspek afektif dan psikomotor.
Keempat, dapat mengembangkan kemampuan berpikir kritis, kreatif, dan reflektif. Hal ini dikarenakan kegiatan pembelajaran ini lebih banyak berpusat pada peserta didik, sehingga peserta didik diberi kesempatan untuk turut serta dalam diskusi kelompok. Pemberian motivasi dari teman sebaya ternyata mampu mendorong semangat peserta didik untuk mengembangkan kemampuan berpikirnya. Terlebih lagi bila pembahasan materi yang sifatnya problematik atau yang bersifat kontroversial, mampu merangsang peserta didik me-ngembangkan kemampuan berpikirnya.

Kelima, mampu mengembangkan kesadaran pada diri peserta didik terhadap permasalahan-permasalahan sosial yang terjadi di lingkungan sekitarya. Dengan bekerja kelompok maka timbul adanya perasaan ingin membantu peserta didik lain yang mengalami kesulitan sehingga mampu me-ngembangkan sosial skill peserta didik. Disamping itu pula dapat melatih peserta didik dalam me-ngembangkan perasaan empati maupun simpati pada diri peserta didik.

Keenam, metode cooperative learning mampu melatih peserta didik dalam berkomunikasi seperti berani mengemukakan pendapat, berani dikriik, maupun menghargai pendapat orang lain. Komunikasi interaksi yang terjadi antara guru dengan peserta didik maupun peserta didik dengan peserta didik menimbulkan dialog yang akrab dan kreatif.

\section{Kelemahan}

Di samping kelebihan, metode cooperative learning juga memiliki kelemahan. Kelemahan metode cooperative learning yaitu:

Pertama, kemungkinan akan terjadi ketidakstabilan peserta didik di kelas. akibatnya guru khawatir bahwa akan terjadi keriuhan di kelas karena 
peserta didik kurang teratur bekerja dalam kelompok. Kondisi seperti ini dapat diatasi dengan guru mengkondisikan kelas atau pembelajaran dilakuakan di luar kelas seperti di laboratorium, aula atau di tempat yang terbuka.

Kedua, banyak peserta didik tidak senang apabila disuruh bekerja sama dengan yang lain. Peserta didik yang tekun merasa harus bekerja melebihi peserta didik yang lain dalam grup mereka, sedangkan peserta didik yang kurang mampu merasa minder ditempatkan dalam satu grup dengan peserta didik yang lebih pandai. Peserta didik yang tekun merasa temannya yang kurang mampu hanya menumpang pada hasil jerih payahnya. Hal ini tidak perlu dikhawatirkan sebab dalam cooperative learning bukan kognitifnya saja yang dinilai tetapi dari segi afektif dan psikomotoriknya juga dinilai seperti kerjasama diantara anggota kelompok, keaktifan dalam kelompok serta sumbangan nilai yang diberikan kepada kelompok.

Ketiga, perasaan was-was pada anggota kelompok akan hilangnya karakteristik atau keunikan pribadi peserta didik karena harus menyesuaikan diri dengan kelompok. Karakteristik pribadi tidak luntur hanya karena bekerjasama dengan orang lain, justru keunikan itu semakin kuat bila disandingkan dengan orang lain.

Keempat, banyak peserta didik takut bahwa pekerjaan tidak akan terbagi rata atau secara adil, bahwa satu orang harus mengerjakan seluruh pekerjaan tersebut. Dalam cooperative learning pembagian tugas rata, setiap anggota kelompok harus dapat mempresentasikan apa yang telah didapatnya dalam kelompok sehingga ada pertanggungjawaban secara individu.

\section{DESAIN METODE COOPERATIVE LEARNING}

Terdapat desain penting yang harus diperhatikan dan dilaksanakan oleh guru PAI dalam menggunakan metode cooperative learning dalam pembelajaran PAI. Desain tersebut berisi langkah-langkah krusial untuk dijalankan oleh guru PAI dalam proses pembelajarannya. Adapun desain metode pembelajaran cooperative learning tersebut dalam pembelajaran PAI dapat dijelaskan berikut ini.

\section{Gambar 1: \\ Desain Metode Cooperative Learning dalam Pembelajaran Pendidikan Agama Islam}

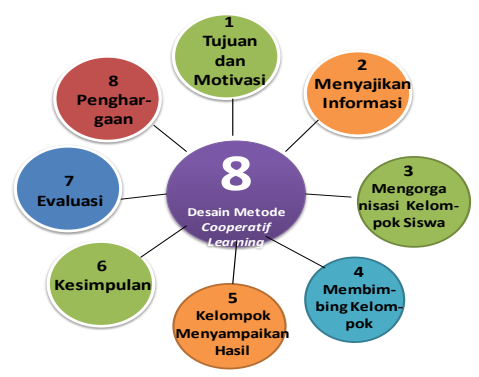

Berdasarkan gambar 1 di atas terdapat 8 (delapan) langkah penting yang harus dilalui oleh guru pendidikana gama Islam (PAI) dalam mempergunakan metode cooperative learning. Delapan langkah tersebut secara umum terbagi kepada 3 (tiga) hal umum yang biasa dilaksanakan 
dalam kegiatan pembelajaran, yaitu kegiatan awal, kegiatan inti, dan kegiatan akhir. Proses pembagian ini dimaksudkan agar guru PAI dapat dengan mudah merancang metode ini dalam rencana pelaksanaan pembelajaran. Hal yang termasuk dalam kegiatan awal adalah tujuan dan motivasi, dan menyajikan informasi. Kegiatan inti adalah mengorganisasi kelompok peserta didik, membimbing kelompok, dan guru meminta kelompok menyampaikan hasil. Kegiatan akhir adalah membuat kesimpulan, melaksanakan evaluasi, dan memberikan penghargaan. Kedelapan langkah tersebut yang telah dirumuskan dalam tabel di atas akan dijelaskan berikut ini.

\section{Menyampaikan Tujuan dan Memotivasi Peserta didik}

Langkah pertama ini seorang guru PAI harus menyampaikan tujuan pembelajaran dan mengkomunikasikan kompetensi dasar yang akan dicapai. Di samping itu juga guru PAI harus memotivasi peserta didik untuk mengikuti pembelajaran PAI tersebut sehingga mereka siap fisik dan mental. Agar proses pendidikan dapat terlaksana dengan baik dan mencapai sasaran, maka salah satu faktor penting yang harus diperhatikan adalah menentukan tujuan dari pembelajaran tersebut. Hal ini pulalah yang menjadikan bahwa setiap kegiatan harus dituntut menetapkan tujuan yang jelas demikian juga halnya dalam metode ini pada setiap kegiatan pembelajaran pendidikan agama Islam. Penetapan tujuan akan menjadi semacam pelurus langkah dalam meneruskan perjalanan dalam penggunaan metode cooperative learning.

Penetapan tujuan dalam metode cooperative learning tidak lepas dari tujuan pembelajaran yang diawali dari indikator pembelajaran yang telah ditetapkan sebelumnya. Indikator yang telah ada sekaligus menjadi seleksi bagi seorang guru PAI atau calon guru lainnya dalam pemelihan metode pembelajaran yang tepat untuk diterapkan pada saat proses pembelajaran PAI. Oleh karena itu siapapun yang akan mengajarkan materi PAI haruslah berhati-hati dan teliti dalam memilah indikator yang ada. Penetapan tujuan dalam metode ini sudah menjadi hal lumrah yang harus ditetapkan oleh guru PAI dalam setiap jenis metode yang dipergunakan.

Pada langkah ini hal penting untuk dilakukan oleh guru PAI dalam pembelajarannya adalah; (1) Guru PAI menyampaikan materi pembelajaran atau permasalahan kepada peserta didik sesuai kompetensi dasar yang akan dicapai; (2) Guru PAI memberikan tes/kuis kepada setiap peserta didik secara individual sehingga akan diperoleh skor awal.

\section{Menyajikan Informasi}

Langkah kedua ini menggambarkan bahwa seorang calon guru atau guru PAI menyajikan informasi terkait dengan materi yang akan diajarkan. Guru PAI menyampaikan materi pembelajaran atau permasalahan kepada peserta didik sesuai kompetensi dasar yang akan dicapai. Informasi tentang apa yang akan dipelajari dan bagaimana proses pembelajaran akan berlangsung menjadi sangat penting bagi peserta didik. Sebab dari informasi inilah seorang peserta didik dapat mempersiapkan dirinya untuk mengikuti pembelajaran PAI dengan baik. Oleh karena itu seorang guru PAI dituntut untuk menguasai metode cooperative learning ini dengan baik hingga dapat menularkannya pada peserta didik. 
Hal penting yang harus diperhatikan dan dilakukan oleh guru PAI dalam menjalankan langkah ini adalah; (1) guru PAI menginformasikan tentang prosedur pembelajaran yang akan dilaksanakan dengan menggunakan metode cooperative learning; (2) guru PAI menginformasikan bahwa metode cooperative learning menuntut peserta didik untuk bekerja sama dalam kelompok dalam proses pembelajarannya; (3) guru PAI menginformasikan alokasi waktu yang dipergunakan dalam proses pembelajaran dengan menggunakan metode cooperative learning; (4) guru PAI memberikan penegasan pada peserta didik terkait dengan pemahaman peserta didik atas prosedur pembelajaran dengan cooperative learning.

\section{Mengorganisasi Peserta Didik dalam Kelompok}

Langkah ketiga ini, seorang calon guru atau guru PAI harus mengorganisasikan peserta didik ke dalam kelompok-kelompok belajar. Hal ini mengindikasikan bahwa seorang guru PAI menginformasikan pengelompokan belajar peserta didik hingga mereka dapat membentuk kelompok-kelompok kecil untuk memulai pembelajaran PAI dengan baik. Pengorganisasian peserta didik ini dalam kelompok sangat penting karena bila keliru dalam menempatkan peserta didik dalam suatu kelompok akan berakibat pada kurang berjalannya pembelajaran. Oleh karena itu, guru PAI harus mendistribusi peserta didik dalam suatu kelompok dengan peserta didik yang heterogen, di mana ada peserta didik yang cerdas, sedang dan kurang, hingga mereka saling mengisi.

Pada langkah ini, seorang guru PAI harus melakukan hal-hal penting, yaitu; (1) Guru PAI membentuk peserta didik ke dalam beberapa kelompok. Setiap kelompok misalnya terdiri dari 4 sampai 5 orang peserta didik dengan kemampuan yang berbeda-beda (tinggi, sedang dan rendah). Jika mungkin anggota kelompok berasal dari ras, budaya, suku yang berbedaserta kesetaraan jender. Dalam beberapa kasus, kelompok dapat dibentuk dengan mempertimbangkan keakraban persahabatan atau minat yang sama dalam topik tertentu; (2) Bahan materi yang telah dipersiapkan didiskusikan dalam kelompok untuk mencapai kompetensi dasar. Pembelajaran kooperatif ini biasanya digunakan untuk penguatan pemahaman materi; (3) Guru PAI mengajukan permasalahan pada peserta didik sesuai dengan indikator pembelajaran untuk dipecahkan bersama dalam kelompok.

\section{Membimbing Kelompok Belajar}

Pada langkah keempat ini, seorang guru PAI memotivasi serta memfasilitasi kerja peserta didik dalam kelompok-kelompok belajar. Pada proses bimbingan ini, seorang guru PAI harus mengetahui dan menyampikan pada peserta didik keterampilanketerampilan yang mesti mereka miliki. Keterampilan ini sangat penting untuk mendukung suksesnya pembelajaran dengan metode cooperative learning ini. Dalam metode ini tidak hanya mempelajari materi saja, tetapi peserta didik atau peserta didik juga harus mempelajari keterampilanketerampilan khusus yang disebut keterampilan kooperatif. Keterampilan kooperatif ini berfungsi untuk melancarkan hubungan kerja dan tugas. Peranan hubungan kerja dapat dibangun dengan membangun tugas anggota kelompok selama kegiatan. Keterampilan-keterampilan selama kooperatif tersebut antara lain sebagai berikut; Pertama, keterampilan kooperatif tingkat awal, yaitu; 
(1) menggunakan

kesepakatan;

(2) menghargai kontribusi; (3) mengambil giliran dan berbagi tugas; (4) berada dalam kelompok; (5) Berada dalam tugas; (6) mendorong partisipasi; (7) mengundang orang lain; (8) menyelesaikan tugas dalam waktunya; (9) menghormati perbedaan individu; Kedua, keterampilan tingat menengah, yaitu; menunjukkan penghargaan dan simpati; mengungkapkan ketidaksetujuan dengan cara dapat diterima; mendengarkan dengan arif; bertanya, membuat ringkasan, menafsirkan, mengorganisir; dan mengurangi ketegangan. Ketiga, keterampilan tingkat mahir, yaitu; mengelaborasi; memeriksa dengan cermat; menanyakan kebenaran; menetapkan tujuan; dan berkompromi.

Pada langkah ini, seorang guru PAI harus melakukan hal-hal penting dalam proses pembelajarannya, yaitu; (1) Guru PAI mengawasi peserta didik terkait dengan tugas yang diberikan untuk mempelajari materi pembelajaran secara individual yang sudah dipersiapkan oleh guru; (2) Peserta didik, di bawah bimbingan guru PAI bekerja dalam kelompok secara kooperatif untuk menuntaskan materi belajarnya; (3) Guru PAI memfasilitasi peserta didik dalam membuat rangkuman, mengarahkan, dan memberikan penegasan pada materi pembelajaran yang telah dipelajari; (4) Selanjutnya peserta didik memilih topik untuk diselidiki, melakukan penyelidikan yang mendalam atas topik yang dipilih itu; (5) Hasil belajar peserta didik secara individual didiskusikan dalam kelompok. Dalam diskusi kelompok, setiap anggota kelompok saling memeriksa jawaban teman satu kelompok.

\section{Meminta Kelompok Menyampaikan Hasil}

Pada langkah kelima ini, seorang guru PAI meminta kelompok masingmasing untuk menyampaikan hasil yang telah ditemukan. Setelah peserta didik berdiskusi dalam kelompok ahli maupun kelompok asal, selanjutnya dilakukan presentasi masing-masing kelompok atau dilakukan pengundian salah satu kelompok untuk menyajikan hasil diskusi kelompok yang telah dilakukan agar guru dapat menyamakan persepsi pada materi pembelajaran yang telah didiskusikan.

Pada langkah ini, seorang guru PAI harus memperhatikan hal-hal penting dalam proses pembelajaranya, yaitu; (1) guru PAI meminta peserta didik mempresentasikan hasil diskusi dalam kelompok di depan kelas; (2) guru PAI meminta kelompok lain untuk memberikan tanggapan terhadap hasil presentasi kelompok yang sedang memberikan hasil kelompok; (3) guru PAI meminta laporan peserta didik secara individu maupun kelompok dalam suatua kelompok dalam bentuk tulisan yang telah tersusun rapih; (4) guru PAI meminta peserta didik lain untuk bersama-sama mengambil insitasari dari hasil kerja sama kelompok yang disesuaikan dengan kompetensi pembelajaran yang telah ditetapkan.

\section{Membuat Kesimpulan}

Pada langkah keenam ini, seorang guru PAI membuat kesimpulan bersama terkait dengan hasil pembelajaran yang telah dilaksanakan dengan metode cooperative learning. Kesimpulan dalam setiap pembelajaran sangatlah dibutuhkan dan oleh karena itu kesimpulan harus dibuat secara bersama-bersama. Membuat kesimpulan ini dapat dilakukan secara bersama- 
sama antara guru dengan peserta didik. Kesimpulan ini untuk menjawab indikator pembelajaran yang telah ditetapkan. Kesimpulan bersama ini sangat penting untuk mendapatkan hasil bersama dan sebagai bentuk nuansa pembelajaran yang demokratis dijunjung tinggi.

oleh Pada tahap ini hal yang dilakukan menggunakan langkah-langkah krusial, yaitu; (1) meminta peserta didik untuk memberikan kesimpulan terhadap materi yang diajarkan dimulai dari masing-masing indikator pembelajaran; (2) meminta peserta didik yang lainnya untuk melengkapi kesimpulan yang telah dikemukakan peserta didik sebelumnya; (3) guru bersama peserta didik mengklasifikasi kesimpulan tersebut sesuai dengan indikator pembelajaran; dan (4) meminta pada peserta didik untuk menuliskan garis besar kesimpulan pembelajaran sesuai dengan indikator pembelajaran pada kertas kerja mereka.

\section{Mengadakan Evaluasi}

Pada langkah ketujuh ini, seorang guru PAI mengadakan evaluasi pembelajaran. Sebagai tindak lanjut setelah diadakannya metode cooperative leraning sering diiringi dengan kegiatan-kegiatan belajar selanjutnya adalah evaluasi. Kegiatan ini dapat berupa pemberian tugas, seperti membuat laporan, menjawab pertanyaan, mengadakan latihan lebih lanjut, apakah di sekolah ataukah di rumah. Selain itu, guru dan peserta didik mengadakan evaluasi terhadap demonstrasi yang dilakukan; apakah berjalan efektif sesuai dengan tujuan yang diharapkan, ataukah ada kelemahan-kelemahan tertentu beserta faktor penyebabnya. Evaluasi dapat dilakukan pada semua aspek yang terlibat dalam demonstrasi tersebut, baik yang menyangkut perencanaan, pelaksanaan, maupun tindak lanjutnya (Arief, 2002: 194).

Cara guru PAI yang relevan dijalankan pada tahapan ini adalah; (1) Guru PAI mengadakan tes pada peserta didik baik lisan, tulisan, atau tindakan terkait dengan materi yang telah dipelajari. (2) Guru bertanya kepada peserta didik terkait keberhasilan penggunaan metode demonstrasi yang dilaksanakan. (3) Guru bertanya kepada peserta didik kelemahan penggunaan metode demonstrasi yang ditemukan dalam proses pembelajaran, berikut solusinya di masa yang akan datang.

\section{Memberikan Penghargaan}

Langkah kedelapan ini, seorang guru PAI harus memberikan penghargaan pada peserta didik yang memiliki kemampuan baik dari semua kelompok belajar yang ada. Penghargaan ini sebenarnya terkait dengan tindak lanjut yang akan dilakukan oleh seorang guru terhadap keberhasilan pembelajaran yang dilaksanakan. Penghargaan ini barangkali sangat penting diperhatikan oleh guru dalam menyukseskan kegiatan pembelajaran dengan metode cooperative learning tersebut.

Maka hal penting yang harus dilakukan oleh seorang calon guru maupun guru PAI yang sekarang ini mengajar untuk menggunakan metode cooperative learning adalah; (1) Guru PAI memperhatikan hasil evaluasi yang telah dilakukan pada tahap sebelumnya sebagai pertimbangan dalam memberikan penghargaan sebagai tindak lanjut; (2) Guru PAI memberi penghargaan pada kelompok berdasarkan perolehan nilai peningkatan hasil belajar individual dari skor dasar ke skor kuis berikutnya (terkini). 


\section{SIMPULAN}

Metode cooperative learning dalam pembelajaran pendidikan agama Islam adalah cara menyajikan pembelajaran dengan belajar bersama berbentuk kelompok kecil yang terstruktur di dalamnya peserta didik melakukan aktivitas belajar saling membantu guna meningkatkan kemampuan kognitif, apektif, dan psikomotorik dalam memahami materi pelajaran dan memecahkan masalah secara kolektif untuk mencapai tujuan yang sama sesuai dengan indikator pembelajaran yang telah ditetapkan.

Berdasarkan definisi terdapat beberapa variabel yang menuntut untuk dijelaskan. Hal ini diperlukan untuk lebih memberikan pemahaman pada calon guru PAI dan juga para guru PAI yang tersebar di seluruh Indonesia mengenai aspek-aspek penting dalam metode cooperative learning tersebut. Untuk itu hal-hal penting yang perlu untuk dijelaskan adalah; Pertama, cara menyajikan pembelajaran. Cara menyajikan ini merupakan langkahlangkah penting yang dipergunakan guru PAI untuk mensukseskan dirinya dalam proses pembelajaran pendidikan agama Islam. Hal yang disajikan oleh guru PAI adalah tentu materi pendidikan agama Islam. Kedua, belajar bersama. Hal ini menggambarkan bahwa peserta didik dalam belajar dengan mengerjakan sesuatu bersamasama dengan saling membantu satu sama lain sebagai satu tim. Cooperatif menyangkut mengerjakan sesuatu bersama-sama dengan saling membantu satu sama lain sebagai satu tim.

Ketiga, berbentuk kelompok kecil yang terstruktur. Berbentuk kelompok kecil di mana peserta didik belajar bersama dalam kelompok yang tidak besar biasanya terdiri dari tiga atau empat orang dan memastikan bahwa setiap orang dalam kelompok mencapai tujuan atau tugas yang telah ditentukan sebelumnya. Pembelajaran bersama berkolompok yang dinamakan terstruktur tersebut termasuk di dalamnya lima unsur pokok yaitu saling ketergantungan positif, tanggung jawab individual, interaksi personal, keahlian bekerja sama, dan proses kelompok. Keempat, peserta didik melakukan aktivitas belajar saling membantu guna meningkatkan kemampuan kognitif, apektif, dan psikomotorik. Di mana menggambarkan bahwa keberhasilan suatu karya sangat bergantung pada usaha setiap anggotanya. Untuk menciptakan kelompok kerja yang efektif, pengajar perlu menyusun tugas sedemikian rupa sehingga setiap anggota kelompok harus menyelesaikan tugasnya sendiri agar yang lain dapat mencapai tujuan mereka.

Kelima dalam memahami materi pelajaran dan memecahkan masalah secara kolektif. Untuk menciptakan suasana tersebut, guru perlu merancang struktur kelompok, tugas-tugas kelompok yang memungkinkan setiap peserta didik untuk belajar mengevaluasi dirinya dengan teman kelompoknya dalam penguasaan dan kemampuan memahami bahan pelajaran. Keenam, untuk mencapai tujuan yang sama sesuai dengan indikator pembelajaran yang telah ditetapkan. Akhir dari proses pembelajaran dengan metode cooperative learning ini adalah di mana semua peserta didik dapat mencapai tujuan pembelajaran sesuai dengan indikator pembelajaran yang telah ditetapkan. Aktivitas belajar peserta didik dalam kelompok di bawah bimbingan guru harus mencapai tujuan tersebut dan peserta didik dapat memahami secara maksimal baik aspek kognitif, apektif dan psikomotorik.

Metode pembelajaran cooperative learning memiliki beberapa keuntungan 
yang diperoleh baik oleh guru maupun peserta didik di dalam pelaksanaan pembelajaran yaitu; Pertama, melalui cooperative learning menimbulkan suasana yang baru dalam pembelajaran. Hal ini dikarenakan sebelumnya hanya dilaksanakan model pembelajaran secara konvensional yaitu camah dan tanya jawab. Metode tersebut ternyata kurang memberi motivasi dan semangat kepada peserta didik untuk belajar. Kedua, membantu guru PAI dalam mengidentifikasikan kesulitan-kesulitan yang dihadapi dan mencarikan alternatif pemecahannya. Dari hasil penelitian tindakan pelaksanaan cooperative learning dengan diskusi kelompok ternyata mampu membuat peserta didik terlibat aktif dalam kegiatan belajar. Ketiga, penggunaan cooperative learning merupakan suatu metode yang efektif untuk mengembangkan program pembelajaran terpadu. Dengan cooperative learning peserta didik tidak hanya dapat mengembangkan kemampuan aspek kognitif saja melainkan mampu mengembangkan aspek afektif dan psikomotor. Keempat, dapat mengembangkan kemampuan berpikir kritis, kreatif, dan reflektif. Hal ini dikarenakan kegiatan pembelajaran ini lebih banyak berpusat pada peserta didik, sehingga peserta didik diberi kesempatan untuk turut serta dalam diskusi kelompok. Kelima, mampu mengembangkan kesadaran pada diri peserta didik terhadap permasalahanpermasalahan sosial yang terjadi di lingkungan sekitarya. Dengan bekerja kelompok maka timbul adanya perasaan ingin membantu peserta didik lain yang mengalami kesulitan sehingga mampu me-ngembangkan sosial skill peserta didik. Disamping itu pula dapat melatih peserta didik dalam mengembangkan perasaan empati maupun simpati pada diri peserta didik. Keenam, metode cooperative learning mampu melatih peserta didik dalam berkomunikasi seperti berani mengemukakan pendapat, berani dikritik, maupun menghargai pendapat orang lain. Komunikasi interaksi yang terjadi antara guru dengan peserta didik maupun peserta didik dengan peserta didik menimbulkan dialog yang akrab dan kreatif.

Di samping kelebihan, metode cooperative learning juga memiliki kelemahan yaitu; Pertama, kemungkinan akan terjadi ketidakstabilan peserta didik di kelas. akibatnya guru khawatir bahwa akan terjadi keriuhan di kelas karena peserta didik kurang teratur bekerja dalam kelompok. Kondisi seperti ini dapat diatasi dengan guru mengkondisikan kelas atau pembelajaran dilakuakan di luar kelas seperti di laboratorium, aula atau di tempat yang terbuka; Kedua, banyak peserta didik tidak senang apabila disuruh bekerja sama dengan yang lain. Peserta didik yang tekun merasa harus bekerja melebihi peserta didik yang lain dalam grup mereka, sedangkan peserta didik yang kurang mampu merasa minder ditempatkan dalam satu grup dengan peserta didik yang lebih pandai. Ketiga, perasaan was-was pada anggota kelompok akan hilangnya karakteristik atau keunikan pribadi peserta didik karena harus menyesuaikan diri dengan kelompok. Keempat, banyak peserta didik takut bahwa pekerjaan tidak akan terbagi rata atau secara adil, bahwa satu orang harus mengerjakan seluruh pekerjaan tersebut.

Terdapat 8 (delapan) langkah penting yang harus dilalui oleh guru pendidikana gama Islam (PAI) dalam mempergunakan metode cooperative learning. Delapan langkah tersebut secara umum terbagi kepada 3 (tiga) hal umum yang biasa dilaksanakan dalam kegiatan pembelajaran, yaitu kegiatan awal, kegiatan inti, dan kegiatan akhir. Proses pembagian ini 
dimaksudkan agar guru PAI dapat dengan mudah merancang metode ini dalam rencana pelaksanaan pembelajaran. Hal yang termasuk dalam kegiatan awal adalah tujuan dan motivasi, dan menyajikan informasi. Kegiatan inti adalah mengorganisasi kelompok peserta didik, membimbing kelompok, dan guru meminta kelompok menyampaikan hasil. Kegiatan akhir adalah membuat kesimpulan, melaksanakan evaluasi, dan memberikan penghargaan. Kedelapan langkah tersebut yang telah dirumuskan dalam tabel di atas akan dijelaskan berikut ini.

Langkah pertama ini seorang guru PAI harus menyampaikan tujuan pembelajaran dan mengkomunikasikan kompetensi dasar yang akan dicapai. Di samping itu juga guru PAI harus memotivasi peserta didik untuk mengikuti pembelajaran PAI tersebut sehingga mereka siap fisik dan mental.

Langkah kedua ini menggambarkan bahwa seorang calon guru atau guru PAI menyajikan informasi terkait dengan materi yang akan diajarkan. Guru PAI menyampaikan materi pembelajaran atau permasalahan kepada peserta didik sesuai kompetensi dasar yang akan dicapai. Informasi tentang apa yang akan dipelajari dan bagaimana proses pembelajaran akan berlangsung menjadi sangat penting bagi peserta didik.

Langkah ketiga ini, seorang calon guru atau guru PAI harus mengorganisasikan peserta didik ke dalam kelompok-kelompok belajar. Hal ini mengindikasikan bahwa seorang guru PAI menginformasikan pengelompokan belajar peserta didik hingga mereka dapat membentuk kelompok-kelompok kecil di mana ada peserta didik yang cerdas, sedang dan kurang, hingga mereka saling mengisi.
Pada langkah keempat ini, seorang guru PAI membimbing, memotivasi serta memfasilitasi kerja peserta didik dalam kelompok-kelompok belajar. Pada proses bimbingan ini, seorang guru PAI harus mengetahui dan menyampikan pada peserta didik keterampilan-keterampilan yang mesti mereka miliki.

Pada langkah kelima ini, seorang guru PAI meminta kelompok masingmasing untuk menyampaikan hasil yang telah ditemukan. Setelah peserta didik berdiskusi dalam kelompok ahli maupun kelompok asal, selanjutnya dilakukan presentasi masing-masing kelompok atau dilakukan pengundian salah satu kelompok untuk menyajikan hasil diskusi kelompok yang telah dilakukan agar guru dapat menyamakan persepsi pada materi pembelajaran yang telah didiskusikan.

Pada langkah keenam ini, seorang guru PAI membuat kesimpulan bersama terkait dengan hasil pembelajaran yang telah dilaksanakan dengan metode cooperative learning. Kesimpulan dalam setiap pembelajaran sangatlah dibutuhkan dan oleh karena itu kesimpulan harus dibuat secara bersama-bersama.

Pada langkah ketujuh ini, seorang guru PAI mengadakan evaluasi pembelajaran. Sebagai tindak lanjut setelah diadakannya metode cooperative leraning sering diiringi dengan kegiatan-kegiatan belajar selanjutnya adalah evaluasi.

Langkah kedelapan ini, seorang guru PAI harus memberikan penghargaan pada peserta didik yang memiliki kemampuan baik dari semua kelompok belajar yang ada. Maka hal penting yang harus dilakukan oleh seorang calon guru maupun guru PAI yang sekarang ini mengajar untuk menggunakan metode cooperative learning adalah; (1) 
Guru PAI memperhatikan hasil evaluasi yang telah dilakukan pada tahap sebelumnya sebagai pertimbangan dalam memberikan penghargaan sebagai tindak lanjut; (2) Guru PAI memberi penghargaan pada kelompok berdasarkan perolehan nilai peningkatan hasil belajar individual dari skor dasar ke skor kuis berikutnya (terkini).

\section{DAFTAR RUJUKAN}

Arief, Armai. 2002. Pengantar Ilmu dan Metodologi Pendidikan Islam. Jakarta: Ciputat Pers.

David and Roger T. Johnson, Cooperative Learning, http//:www.clrcc.com/pages/cl.ht $\mathrm{ml}$

David dan Roger T. Johnson, "Learning Together", dalam Shlomo, Sharan (ed.), Handbook of Cooperative Learning Methods, (Connecticut London: Praeger, 1999), h. 58

Gojwan, Asep, "Pengembangan Model Pembelajaran Kooperatif pada Mata Pelajaran PAI", http://pps.upi.edu/org/
Nasution, S., 2002. Didaktik Azas Mengajar, Bandung: Bumi Aksara.

Nurhadi 2004. Kurikulum 2004; Pertanyaan dan Jawaban. Jakarta: Grasindo.

Riyanto, H. Yatim. 2012. Paradigma Baru Pembelajaran: Sebagai Referensi Bagi Guru/Pendidik dalam Implementasi Pembelajaran yang Efektif dan Berkualitas, cet. ke -3. Jakarta: Kencana Prenada Media Group.

Sagala, Syaiful. 2003. Konsep dan Makna Pembelajaran. Bandung: Alfabeta.

Salvin. 1995. An Introduction to Cooperative Learning Research. London: Plenum Press.

Usman, M. Basyiruddin. 2002. Metode Pembelajaran Agama Islam. Jakarta: Ciputat Press.

Wehmeier, Sally. 2000. Oxford Advanced Learner's Dictionary. New York: Oxford University Press.

Woofolk, Anita E., 1996. Educational Psychology, cet. ke -4. USA: Allyn \& Bacon.

Yurnetti, "Pembelajaran Kooperatif Sebagai Model Alternatif", Jurnal Himpunan Fisika Indonesia, Volume B5, Agustus 2002. 